\title{
Ending overly broad criminalization of nondisclosure of human immunodeficiency virus infection
}

\author{
Richard Elliott LLB LLM
}

Cite as: CMAJ 2018 November 19;190:E1348-9. doi: 10.1503/cmaj.181405

See related article at www.cmaj.ca/lookup/doi/10.1503/cmaj.180311

$\mathbf{T}$ here are good public health and human rights rationales for ending the overly broad, unjust use of the criminal law to prosecute allegations of nondisclosure of HIV. ${ }^{1}$ In linked research, LeMessurier and colleagues estimate risk of HIV transmission under various conditions. ${ }^{2}$ As they state, this work was undertaken to inform Department of Justice Canada's examination of the criminal justice system's response to HIV nondisclosure, following the minister's recognition that "overcriminalization of HIV" contributes to HIV stigma and undermines public health, and that "the criminal justice system must adapt to better reflect the current scientific evidence." ${ }^{3}$ However, categorizations of risk used in public health do not necessarily match understandings of risk applied in the criminal courts. Consequently, the qualitative conclusions presented in the linked review may overstate to the criminal justice system the riskiness of various acts.

In an analysis intended to inform the criminal justice system, LeMessurier and colleagues' qualitative assessments of transmission risk apply risk categories originally developed 30 years ago to enable public education about safer sex and health risk reduction in general. These categories reflect the relative riskiness of different activities. But they should not be transposed into a system tasked with determining criminal liability based on risk associated with a single act.

Under current law, the central question before a criminal court is this: Should this particular individual, accused of not disclosing their HIV-positive status before a specific sexual act, be found criminally liable based on a sufficiently substantial risk of transmission? The most common charge is aggravated sexual assault, which carries a maximum penalty of life imprisonment and mandatory registration as a sex offender. ${ }^{4}$ That is, based on perceived risk, HIV nondisclosure in the context of a consensual sexual encounter is treated as legally equivalent to rape - and prosecutions and convictions continue even where there is little or no risk of transmission. ${ }^{5}$

\section{KEY POINTS}

- Current Canadian law allows a person to be convicted for nondisclosure of HIV in the context of a consensual sexual encounter if there is a "realistic possibility" of transmission.

- The criminal justice system's understanding of transmission risk is key in determining the scope of criminalization of people living with HIV.

- Qualitative risk categories that describe the relative riskiness of different sexual activities, developed for broad public education about safer sex, should not be applied uncritically in the criminal justice system, which is concerned with determining criminal liability based on risk associated with a single act.

- Canadian and international scientific consensus statements, developed specifically to ensure that criminal justice correctly appreciates the best available science about HIV, provide useful guidance that should be relied upon by prosecutors, defence lawyers and courts.

- Such statements recognize that the per-act possibility of HIV transmission associated with various sexual acts ranges from zero to negligible to low, warranting a much more limited application of the criminal law than is currently the case.

The authors of the linked research characterize sex with a condom alone as the sole risk-reducing factor as posing a "low" risk of HIV transmission. The risk is still characterized as low for the situation where either partner uses a condom and the HIV-positive partner is taking antiretroviral therapy (with varying levels of viral load). However, HIV cannot pass through an intact condom used correctly; the risk of transmission is none in most individual circumstances of condom use or negligible, at most, in the infrequent event of individual condom breakage.

The study authors also characterize the risk as "negligible" in the scenario where the HIV-positive partner has a suppressed viral load (less than 200 copies $/ \mathrm{mL}$ ). Yet, as Canada's chief medical officers of health have recognized, viral suppression per se 
means there is "effectively no risk" of transmission, ${ }^{6}$ which is summed up in the global consensus that "undetectable = untransmittable" ("U = U"). ${ }^{7}$ Several of the studies included in the linked review showed zero transmissions per 100 personyears under those circumstances. The authors still characterize the risk as negligible even where, in addition to viral suppression in the HIV-positive partner, either partner uses a condom through which the virus cannot pass, as already noted. Again, the characterization of risk uses qualitative descriptors not fit for the intended purpose.

In 2014, nearly 80 scientists issued the Canadian consensus statement on HIV and its transmission in the context of the criminal law, which was "developed ... out of a concern that the criminal law is being used in an overly broad fashion against people living with HIV in Canada because of, in part, a poor appreciation of the scientific understanding of HIV and its transmission." ${ }^{8}$ Recently, the international scientific community released the global, peer-reviewed Expert consensus statement on the science of HIV in the context of the criminal law. ${ }^{5}$ Endorsed by 90 leading HIV scientists from every region of the world, as well as the International AIDS Society, the International Association of Providers of AIDS Care and the Joint United Nations Programme on HIV/AIDS (UNAIDS), the statement provides the most current comprehensive assessment of the available science, again with a view to assisting actors in the criminal justice system to limit unscientific prosecutions.

Both these consensus statements conclude that the per-act possibility of HIV transmission exists on a continuum running from no to negligible to low possibility and provide clear definitions of those terms. Both statements were produced specifically to inform the criminal justice system. In contrast, the characterizations of risk within the linked research study, intended for public health education purposes, would be misapplied in the context of criminal justice.

The Department of Justice Canada has concluded that prosecution of HIV nondisclosure is not warranted in cases where a person has a suppressed viral load and that the criminal law should generally not be applied to prosecute HIV nondisclosure in cases where a person is on antiretroviral treatment, or uses condoms or simply for engaging in oral sex, "because the realistic possibility of transmission test [set out by the Supreme Court of Canada] is likely not met" ${ }^{9}$ in those circumstances.

It is essential to be mindful of different characterizations of risk between different professional disciplines for different purposes; consensus statements of expert scientific opinion that specifically address the needs of the criminal justice system should guide that system.

\section{References}

1. Ending overly broad criminalisation of HIV non-disclosure, exposure and transmission: critical scientific, medical and legal considerations. Geneva: UNAIDS; 2013.

2. LeMessurier J, Traversy G, Varsaneux O, et al. Risk of sexual transmission of human immunodeficiency virus with antiretroviral therapy, suppressed viral load and condom use: a systematic review. CMAJ 2018;190:E1350-60.

3. Minister Wilson-Raybould issues statement on World AIDS Day [statement]. Ottawa: Department of Justice Canada; 2016 Dec. 1.

4. Hastings C, Kazatchkine C, Mykhalovskiy E. HIV criminalization in Canada: key trends and patterns [report]. Ottawa: Canadian HIV/AIDS Legal Network; 2017 Mar. 17.

5. Barré-Sinoussi F, Abdool Karim SS, Albert J, et al. Expert consensus statement on the science of HIV in the context of criminal law. J Int AIDS Soc 2018; 21:e25161.

6. Statement on behalf of the Council of Chief Medical Officers of Health [statement]. Ottawa: Public Health Agency of Canada; 2017 Nov. 30.

7. Risk of sexual transmission of HIV from a person living with HIV who has an undetectable viral load. Prevention Access Campaign: 2016 July 21 (updated 2018 Aug. 23). Available: www.preventionaccess.org/consensus (accessed 2018 Oct. 30).

8. Loutfy M, Tyndall M, Baril J-G, et al. Canadian consensus statement on HIV and its transmission in the context of the criminal law. Can J Infect Dis Med Microbiol 2014;25:135-40.

9. Criminal justice system's response to non-disclosure of HIV [report]. Ottawa: Department of Justice Canada; 2017 Dec. 1. Available: www.justice.gc.ca/eng/ rp-pr/other-autre/hivnd-vihnd/hivnd-vihnd.pdf (accessed 2018 Oct. 30).

\section{Competing interests: None declared.}

This article was solicited and has been peer reviewed.

Affiliation: Canadian HIV/AIDS Legal Network, Toronto, Ont.

Correspondence to: Richard Elliott, relliott@aidslaw.ca 